Provided for non-commercial research and education use. Not for reproduction, distribution or commercial use.

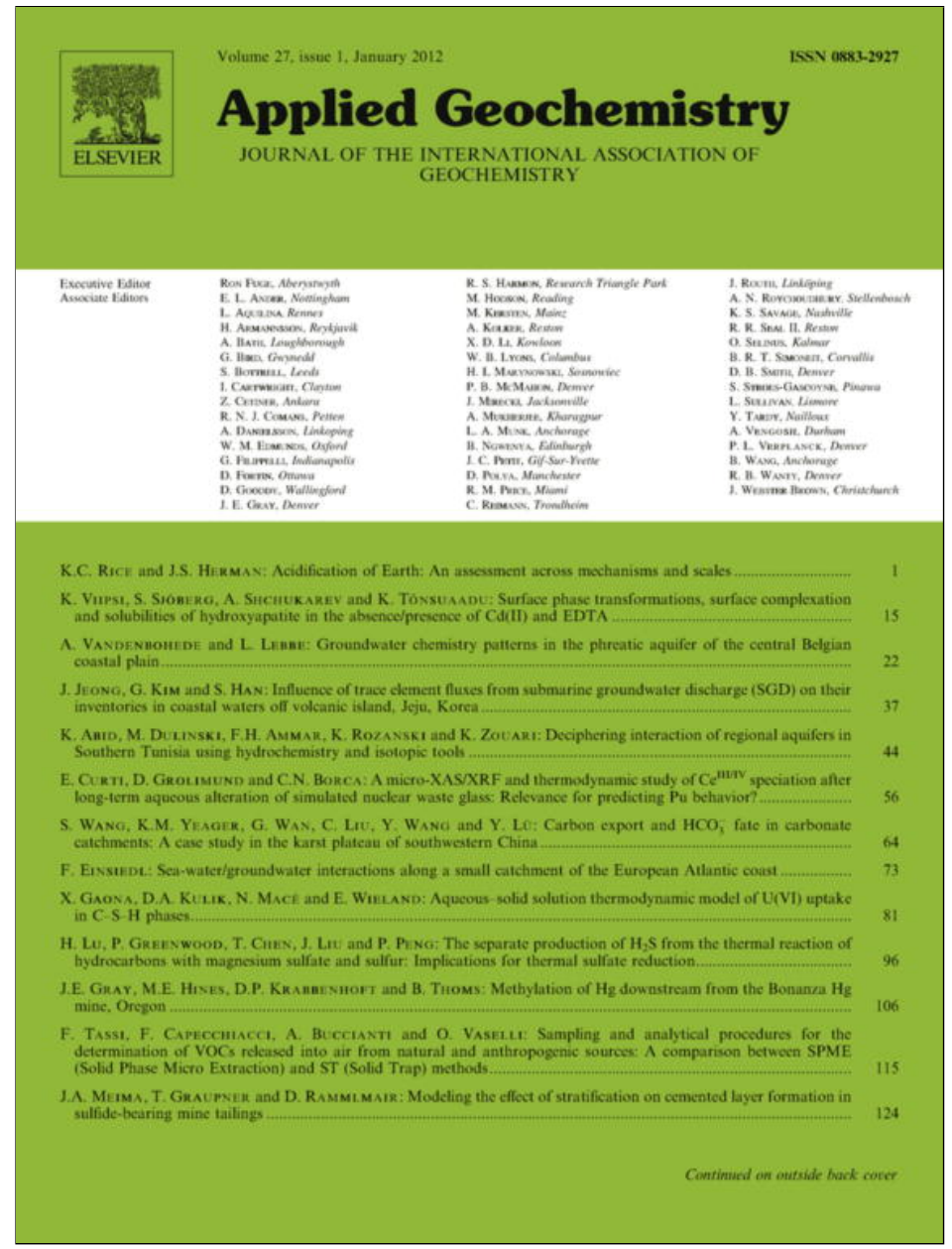

This article appeared in a journal published by Elsevier. The attached copy is furnished to the author for internal non-commercial research and education use, including for instruction at the authors institution and sharing with colleagues.

Other uses, including reproduction and distribution, or selling or licensing copies, or posting to personal, institutional or third party websites are prohibited.

In most cases authors are permitted to post their version of the article (e.g. in Word or Tex form) to their personal website or institutional repository. Authors requiring further information regarding Elsevier's archiving and manuscript policies are encouraged to visit:

http://www.elsevier.com/copyright 


\title{
Recent paleorecords document rising mercury contamination in Lake Tanganyika
}

\author{
Christopher H. Conaway ${ }^{\mathrm{a}, *}$, Peter W. Swarzenski ${ }^{\mathrm{a}}$, Andrew S. Cohen ${ }^{\mathrm{b}}$ \\ ${ }^{a}$ United States Geological Survey, 400 Natural Bridges Drive, Santa Cruz, CA 95060, USA \\ ${ }^{\mathrm{b}}$ Department of Geosciences, University of Arizona, 1040 E 4th Street, Tucson, AZ 85721, USA
}

\section{A R T I C L E I N F O}

\section{Article history:}

Received 7 May 2011

Accepted 4 November 2011

Available online 13 November 2011

Editorial handling by J. Gray

\begin{abstract}
A B S T R A C T
Recent Lake Tanganyika Hg deposition records were derived using ${ }^{14} \mathrm{C}$ and excess ${ }^{210} \mathrm{~Pb}$ geochronometers in sediment cores collected from two contrasting depositional environments: the Kalya Platform, located mid-lake and more removed from watershed impacts, and the Nyasanga/Kahama River delta region, located close to the lake's shoreline north of Kigoma. At the Kalya Platform area, pre-industrial Hg concentrations are $23 \pm 0.2 \mathrm{ng} / \mathrm{g}$, increasing to $74 \mathrm{ng} / \mathrm{g}$ in modern surface sediment, and the $\mathrm{Hg}$ accumulation rate has increased from 1.0 to $7.2 \mu \mathrm{g} / \mathrm{m}^{2} / \mathrm{a}$ from pre-industrial to present, which overall represents a 6fold increase in $\mathrm{Hg}$ concentration and accumulation. At the Nyasanga/Kahama delta region, pre-industrial $\mathrm{Hg}$ concentrations are $20 \pm 3 \mathrm{ng} / \mathrm{g}$, increasing to $46 \mathrm{ng} / \mathrm{g}$ in surface sediment. Mercury accumulation rate has increased from 30 to $70 \mu \mathrm{g} / \mathrm{m}^{2} / \mathrm{a}$ at this site, representing a 2-3-fold increase in $\mathrm{Hg}$ concentration and accumulation. There is a lack of correlation between charcoal abundance and $\mathrm{Hg}$ accumulation rate in the sediment cores, demonstrating that local biomass burning has little relationship with the observed $\mathrm{Hg}$ concentration or $\mathrm{Hg}$ accumulation rates. Examined using a sediment focusing-corrected mass accumulation rate approach, the cores have similar anthropogenic atmospheric $\mathrm{Hg}$ deposition profiles, suggesting that after accounting for background sediment concentrations the source of accumulating Hg is predominantly atmospheric in origin. In summary, the data document an increase of Hg flux to the Lake Tanganyika ecosystem that is consistent with increasing watershed sediment delivery with backgroundlevel $\mathrm{Hg}$ contamination, and regional as well as global increases in atmospheric $\mathrm{Hg}$ deposition.
\end{abstract}

Published by Elsevier Ltd.

\section{Introduction}

Mercury contamination from mining activity and fossil fuel combustion has impacted aquatic ecosystems worldwide (Fitzgerald et al., 1998). It is generally accepted that there has been a 3-5-fold increase in atmospheric $\mathrm{Hg}$ deposition rates since the beginning of global industrialization in the late 19th century (Biester et al., 2007). Quantifying such contamination relies on evaluation of the accumulation and historical deposition of $\mathrm{Hg}$ (Lamborg et al., 2002; Strode et al., 2009). However, there are few such studies from the Southern Hemisphere (Lamborg et al., 2002; Ramlal et al., 2003; Cooke et al., 2009; Kading et al., 2009; Yang et al., 2010), particularly Africa (Campbell et al., 2003; Kading et al., 2009; Yang et al., 2010). Previous studies in Africa have suggested that regional sources of $\mathrm{Hg}$, such as artisanal mining, are relatively important compared to global sources (Selin et al., 2008; Kading et al., 2009), and where unregulated Au mining practices are common (Taylor et al., 2005).

Lake sediment cores are an important tool for reconstructing $\mathrm{Hg}$ depositional trends in order to determine changes in local, regional, and global $\mathrm{Hg}$ fluxes to the environment. The importance of

\footnotetext{
* Corresponding author.

E-mail address: cconaway@usgs.gov (C.H. Conaway).
}

atmospheric $\mathrm{Hg}$ deposition and contamination in remote ecosystems as a result of global fossil fuel combustion is well known (Fitzgerald et al., 1998). In addition, the local and regional effect of mining and other industrial activities has been documented in many places (Landers et al., 1998; Lamborg et al., 2002; Cooke et al., 2009). The modelling of the regional and global effects of $\mathrm{Hg}$ from these emission sources relies on data from sediment cores (Selin et al., 2008; Strode et al., 2009). Additional data where global coverage is sparse, such as equatorial Africa, provides a test for global atmospheric $\mathrm{Hg}$ deposition models and an understanding of the relative importance of regional sources of $\mathrm{Hg}$ to these understudied areas.

Lake Tanganyika (Fig. 1) is a large, permanently stratified tropical rift lake south of the equator $\left(4-9^{\circ} S\right)$ that supports a rich, diverse, and highly endemic aquatic ecosystem (Coulter, 1991). The lake also supports large fisheries, which are a critical regional source of food (Reynolds et al., 1999). The importance of the lake as a biotic and economic resource is widely recognized (Cohen et al., 1996), and has led to the establishment of the UN-funded Lake Tanganyika Biodiversity Project (LTBP) to investigate threats to the lake and its watershed, and more recently the establishment of the Lake Tanganyika Authority to manage the lake. Because of the paucity of long-term ecological and limnological records on the lake, the LTBP recognized the importance of collecting paleoda- 


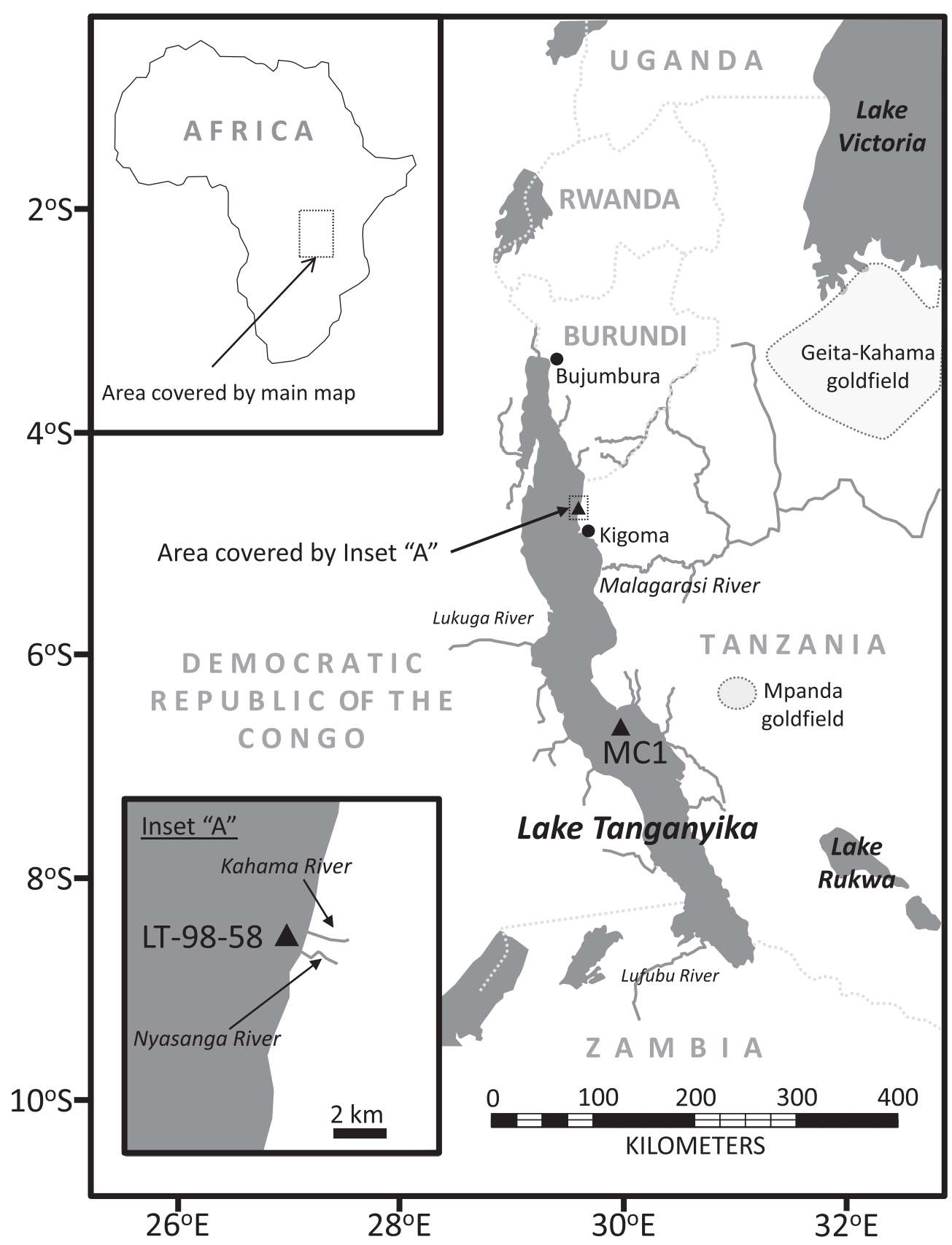

Fig. 1. Core locations (shown by solid triangles) in Lake Tanganyika, East Africa. Location of MC1 is over the Kalya Platform area of the lake, and LT-98-58 (shown in Inset "A") is at the Nyasanga/Kahama River delta. Locations and outlines of nearby important goldfields are taken from Kuehn et al. (1990). The Musoma-Mara goldfield (not shown) lies further to the east, on the shores of Lake Victoria.

ta from lake-core records to document the timing and magnitude of anthropogenic disturbance and climate change in the lake and its watershed (Cohen et al., 2005a). River deltas were recognized in these studies as key areas for collecting sediment cores in an effort to understand the history of watershed disturbance. A large number of lake sediment cores have been collected from river deltas as well as more offshore areas in Lake Tanganyika to investigate the effect of human activities around the lake basin (Cohen et al., $2005 \mathrm{~b}$ ), and also to investigate the effect of regional and global climate changes (Cohen et al., 2005b; Tierney et al., 2010).

Large-scale mining and production of $\mathrm{Au}$ in the region, utilizing $\mathrm{Hg}^{0}$ for Au recovery, began in the 1930 s and continued until the 1970 s, resulting in substantial production at the Geita mines and Musoma-Mara Au field (Kuehn et al., 1990; Foster and Piper,
1993). In the late 20th and early part of the 21st century, $\mathrm{Hg}^{0}$ has also been widely used in artisanal and small-scale Au mining in the region (Ikingura et al., 1997; Taylor et al., 2005). A study by Taylor et al. (2005) of watershed inputs from Au mining from the Geita District, Tanzania, which flows several hundred kilometres via the Malagarasi River into Lake Tanganyika, suggested that there was little discernable effect of Au mining in the Malagarasi watershed on $\mathrm{Hg}$ concentrations in fish in Lake Tanganyika. This lack of impact was attributed to the extensive swamps and flooded grasslands between the Au fields and Lake Tanganyika inhibiting watershed transport of $\mathrm{Hg}$. There has also been $\mathrm{Hg}$-assisted Au production in the Mpanda Au field, which is closer (about $100 \mathrm{~km}$ ) to the lake than the Geita District. Despite its proximity, the Mpanda Au field drains to Lake Rukwa to the SE (Kuehn et al., 1990; Foster 
and Piper, 1993), and not to Lake Tanganyika, thus limiting any potential Hg contamination to Lake Tanganyika from the Mpanda Au field to atmospheric pathways.

The potential for $\mathrm{Hg}$ contamination in the region is not limited to Au mining sources. Sediment samples taken from where the Malagarasi River enters Lake Tanganyika are elevated in $\mathrm{Hg}$ $(100-660 \mathrm{ng} / \mathrm{g})$ compared to regional background sites (80$90 \mathrm{ng} / \mathrm{g}$ ) at Munekesi and Nyamasenga. The relatively high $\mathrm{Hg}$ concentration in sediment is attributed to differences in sediment lithology, geothermal springs at Uvinza, and the use of mercuric soap for skin lightening (Taylor et al., 2005). Skin lightening soaps can have alarming $\mathrm{Hg}$ content (up to $2 \%$ as mercury iodide) and are commonly used by people in the region (Harada et al., 2001). In addition, there are many industrial facilities at Bujumbura, Burun$\mathrm{di}$, including battery production, that are potential sources of metals (including $\mathrm{Hg}$ ) and that discharge wastewater into the northern end of Lake Tanganyika. There is also potential regional atmospheric Hg contamination from cement production in the Democratic Republic of the Congo (West, 2001). Biomass burning, which is widespread in the tropics in general (Crutzen and Andreae, 1990) and in the Lake Tanganyika region in particular (Cohen et al., 2005a,b; Palacios-Fest et al., 2005), has been recognized as a substantial regional and global source of atmospheric $\mathrm{Hg}$ (Brunke et al., 2001; Weiss-Penzias et al., 2007; Friedli et al., 2009) as well as a source of increased, direct $\mathrm{Hg}$ released to watersheds (Veiga et al., 1994). Atmospheric contamination with $\mathrm{Hg}$ has been documented in nearby equatorial lakes $\left(0^{\circ} 22^{\prime} \mathrm{N}, 29^{\circ} 55^{\prime} \mathrm{E}\right)$ in Rwenzori Mountains, Uganda (Yang et al., 2010). However, that study did not consider regional atmospheric sources, but rather emphasized the increase of atmospheric $\mathrm{Hg}$ resulting from global industrialization.

Consequently, given the extensive local and regional sources of both watershed and atmospheric $\mathrm{Hg}$, historical deposition of $\mathrm{Hg}$ was investigated in sediment cores collected from two sites on the eastern side of Lake Tanganyika. These cores were dated using ${ }^{14} \mathrm{C}$ and excess ${ }^{210} \mathrm{~Pb}$ geochronometers and analyzed for $\mathrm{Hg}$ concentration. The objective of this study was to document past and current anthropogenic contributions of $\mathrm{Hg}$ to the lake, and to examine possible regional differences within the lake that might constrain Hg sources.

\section{Methods}

For the current study, material from two cores taken for previous studies with reliable excess ${ }^{210} \mathrm{~Pb}$ chronology collected in areas of relatively low disturbance from local anthropogenic activity was used. Core MC1 $\left(6.5525^{\circ} \mathrm{S}, 29.9747^{\circ} \mathrm{E}\right)$ was collected in $309 \mathrm{~m}$ water depth (below the oxycline) from the Kalya Platform area (Tierney et al., 2010) in the south-central part of the lake, near the Mahale Mountains, which are sparsely populated and show little influence of anthropogenic activity. Core LT-98-58 $\left(4.6883^{\circ} \mathrm{S}\right.$, $29.6167^{\circ} \mathrm{E}$ ) was collected in $76 \mathrm{~m}$ water depth (typically dysoxic conditions) from the Nyasanga/Kahama delta region in northern Tanzania, offshore from Gombe Stream National Park (McKee et al., 2005). The watershed regions of the Nyasanga/Kahama deltas are entirely within Gombe Stream National Park and there is no knowledge of any Au mining activity that has occurred in that area. Detailed methods and results of paleobiological, sedimentological, geochemical and geochronological analyses on core LT98-58 are presented in a series of papers introduced by Cohen et al. (2005a).

The geochronology and mass sedimentation rate is presented and discussed in detail in Tierney et al. (2010) for MC1, and in McKee et al. (2005) for LT-98-58. In both cases, an age model was derived using a constant rate of supply (CRS) method addition- ally constrained by accelerator mass spectrometry ${ }^{14} \mathrm{C}$ data. Both cores showed an exponential downcore decrease in unsupported ${ }^{210} \mathrm{~Pb}$ activity, readily interpretable as a constant sediment accumulation rate $(0.05 \mathrm{~cm} / \mathrm{a}$ in MC1, $0.15 \mathrm{~cm} / \mathrm{a}$ in LT-98-58). Ultramodern ${ }^{14} \mathrm{C}$ age dates (i.e., more recent than the 1950 onset of nuclear testing) for LT-98-58 are consistent with the ${ }^{210} \mathrm{~Pb}$ age model (McKee et al., 2005). One ${ }^{14} \mathrm{C}$ age determination (290 a B.P.) on a plant fragment at $18-19 \mathrm{~cm}$ in LT-98-58 is not consistent with the ${ }^{210} \mathrm{~Pb}$ age model, presumably because the organic material dated represents older, reworked material. However, a ${ }^{14} \mathrm{C}$ derived calendar age of 1759 on a plant fragment collected at 37$38 \mathrm{~cm}$ is in good agreement with the ${ }^{210} \mathrm{~Pb}$ age model.

Charcoal analyses were also previously performed on samples collected from a parallel multi-core barrel for LT-98-58 (PalaciosFest et al., 2005), and on samples collected from the same core for MC1 (Tierney et al., 2010). In both cases, charcoal abundance was estimated by disaggregating and wet-sieving samples (125 $\mu \mathrm{m}$ mesh size for MC1, and $106 \mu \mathrm{m}$ for LT-98-58) and counting the charred particles retained on the sieve using a stereomicroscope. The determination of abundance based on this relatively coarse $(>100 \mu \mathrm{m})$ fraction of charcoal provides a good indication of local, within watershed production rather than long-distance aerial transport (Palacios-Fest et al., 2005).

Sediment total $\mathrm{Hg}$ analyses for this study were conducted by digesting sediment $(0.3 \mathrm{~g})$ in boiling $\mathrm{HNO}_{3} / \mathrm{H}_{2} \mathrm{SO}_{4}$ (7:3), followed by 12 -h oxidation with $\mathrm{BrCl}, \mathrm{SnCl}_{2}$-reduction, Au-amalgamation, and detection by CVAFS (Bloom and Crecelius, 1987; Gill and Fitzgerald, 1987). Analyses $(n=5)$ of MESS-3, a marine sediment certified reference material from the National Research Council of Canada, yielded a mean $(x \pm \sigma)$ concentration of $0.094 \pm$ $0.003 \mu \mathrm{g} \mathrm{g}^{-1}$ (certified value $0.091 \pm 0.009 \mu \mathrm{g} \mathrm{g}^{-1}$ ). The analytical detection limit, calculated using three times the standard deviation of the procedural blanks $(n=6)$, was $0.0026 \mu \mathrm{g} \mathrm{g}^{-1}$. For MC1, all samples were digested and analyzed in duplicate, and the relative percent difference (RPD) between paired results was better than $8 \%$, with a mean RPD of $6 \%$. For core LT-98-58, the RPD on sample digestion duplicates $(n=3)$ was $3 \pm 4 \%$, and the RPD on sample analytical duplicates $(n=3)$ was $2 \pm 1 \%$.

\section{Results and discussion}

As discussed elsewhere, both of the coring sites show little local anthropogenic watershed impacts related to nutrient and sediment pollution, such as deforestation or agricultural activity (Cohen et al., 2005b; Tierney et al., 2010), which have been detected at other locations in the lake region (Cohen et al., 2005a,b). The estimate for mass accumulation rates at the MC1 coring site is $0.002-$ $0.01 \mathrm{~g} / \mathrm{cm}^{2} / \mathrm{a}$ (Fig. 2), with an average of about $0.006 \mathrm{~g} / \mathrm{cm}^{2} / \mathrm{a}$ below $5 \mathrm{~cm}$ depth (representing about 1910 in the age model), and increasing from about 0.006 to $0.01 \mathrm{~g} / \mathrm{cm}^{2} / \mathrm{a}$ from $5 \mathrm{~cm}$ depth to the surface. The mass accumulation rate at the LT-98-58 coring site $\left(0.1-0.2 \mathrm{~g} / \mathrm{cm}^{2} / \mathrm{a}\right)$ is over an order of magnitude higher than the MC1 coring site $\left(0.002-0.01 \mathrm{~g} / \mathrm{cm}^{2} / \mathrm{a}\right)$, which reflects the greater distance to shore and so to riverine sediment sources of MC1 compared to LT-98-58 (McKee et al., 2005; Tierney et al., 2010). Differences in the two sites likely reflect varying degrees of sediment focusing, watershed size, watershed sediment delivery, and water column $\mathrm{O}_{2}$ concentrations. The Nyasanga/Kahama delta region (i.e., LT-98-58) lies in closer proximity to both the high human population densities and regional burning associated with the extensive deforestation of the northern part of the lake basin than does Kalya Platform area (MC1), which lies far from any significant population centers.

Below a depth of $8 \mathrm{~cm}$ (model age $1830 \mathrm{AD}$ ), $\mathrm{Hg}$ concentrations in MC1 are a relatively low $23 \pm 2 \mathrm{ng} / \mathrm{g}$ (Figs. 3 and 4). Between 6 


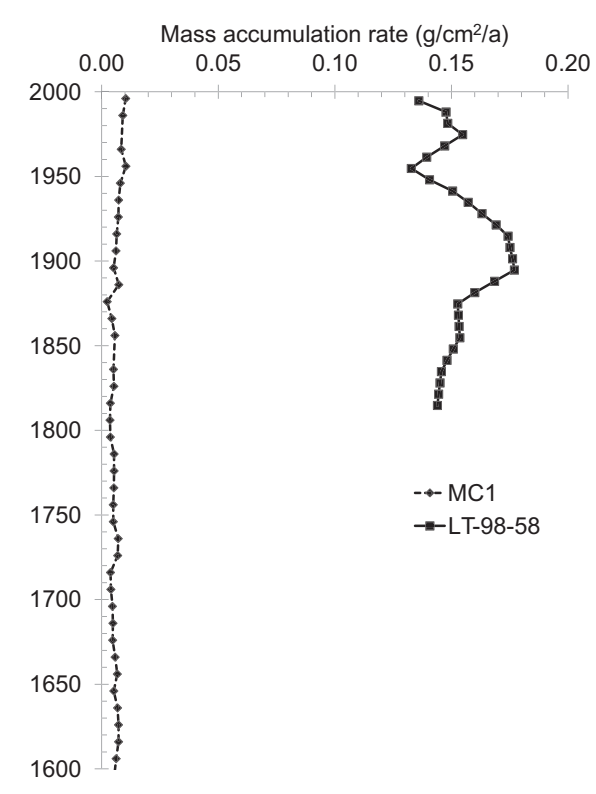

Fig. 2. Mass accumulation rates $\left(\mathrm{g} / \mathrm{cm}^{2} / \mathrm{a}\right)$ in cores MC1 and LT-98-58.

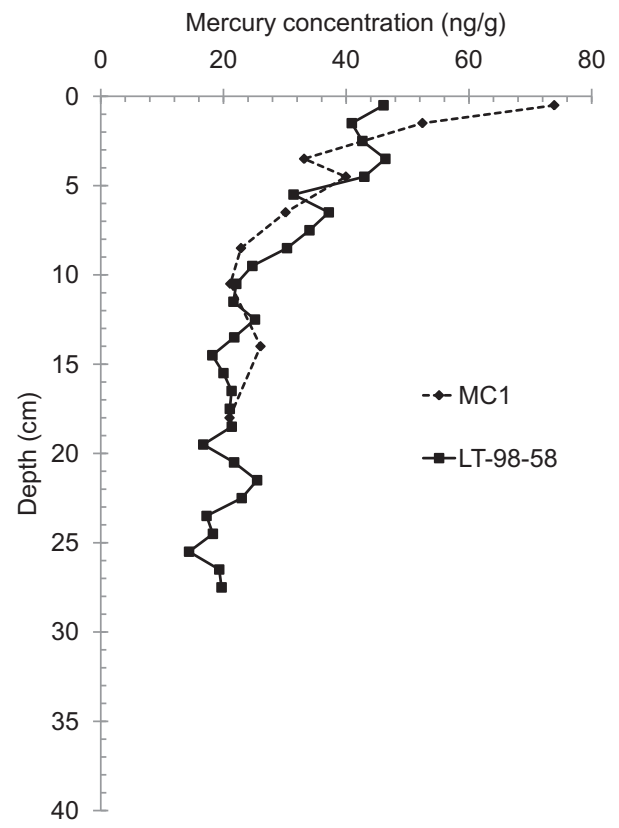

Fig. 3. Vertical distribution of total Hg concentration (ng/g) in cores MC1 and LT98-58.

and $8 \mathrm{~cm}$ (model age 1830-1870), Hg concentrations increase slightly. This initial increase potentially corresponds to the beginning of global $\mathrm{Hg}$ contamination from the industrial revolution in the late 19th century (i.e., contamination from coal burning worldwide). Between 3 and $6 \mathrm{~cm}$ (model age 1870-1930) sediment $\mathrm{Hg}$ concentrations are $34 \pm 5 \mathrm{ng} / \mathrm{g}$. A large increase of sediment $\mathrm{Hg}$ concentration ( $>50 \mathrm{ng} / \mathrm{g}$ ) above $3 \mathrm{~cm}$ (model age 1930) is consistent with $\mathrm{Hg}$ profiles in dated cores from Lake Victoria (Campbell et al., 2003; Ramlal et al., 2003) and South Africa (Kading et al., 2009), and with the onset of large-scale Au production and other development in the region in the 1930s. Although this link to regional Au mining sources is consistent with the idea that local and regional sources of $\mathrm{Hg}$ may be more important than global $\mathrm{Hg}$ sources in some parts of Africa (Kading et al., 2009), it is diffi-

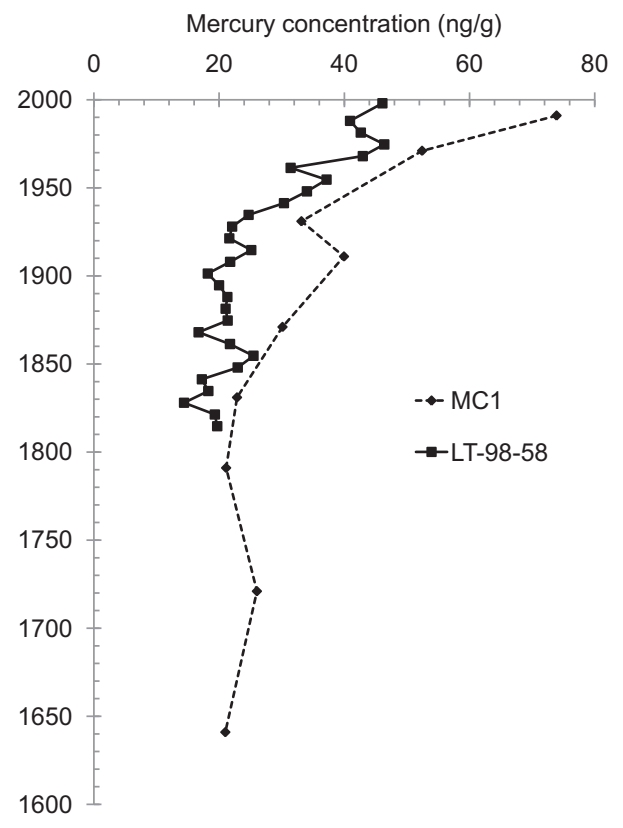

Fig. 4. Age model of total Hg concentration (ng/g) in cores MC1 and LT-98-58.

cult to distinguish such a trend from the overall 20th century increase in atmospheric $\mathrm{Hg}$ deposition that is generally attributed to the global rise in anthropogenic emissions (Fitzgerald et al., 1998; Lamborg et al., 2002; Biester et al., 2007).

Concentrations of $\mathrm{Hg}$ in LT-98-58 are lower $(20 \pm 3 \mathrm{ng} / \mathrm{g})$ in the deeper part of the core ( $>10 \mathrm{~cm}$ depth) compared to the upper part of the core (Figs. 3 and 4). The depth of $10 \mathrm{~cm}$ in this core corresponds to about 1930-1940 in the age model. From $10 \mathrm{~cm}$ depth to the top of LT-98-58, Hg concentrations increase from about 20 to $46 \mathrm{ng} / \mathrm{g}$. As observed in MC1, the onset of increased Hg accumulation beginning in 1930-1940 is consistent with known regional and global increases in industrial activity and $\mathrm{Hg}$ emissions (Kuehn et al., 1990; Foster and Piper, 1993; Ikingura et al., 1997; Fitzgerald et al., 1998; Lamborg et al., 2002; Ramlal et al., 2003; Hartnady, 2009; Kading et al., 2009).

The sediment mass accumulation rate for MC1 is $0.002-0.01 \mathrm{~g} /$ $\mathrm{cm}^{2} / \mathrm{a}$ (Fig. 2), and the corresponding $\mathrm{Hg}$ accumulation rate is about $1.2 \mu \mathrm{g} / \mathrm{m}^{2} / \mathrm{a}$ below $5 \mathrm{~cm}$, increasing to $7.2 \mu \mathrm{g} / \mathrm{m}^{2} / \mathrm{a}$ at the top of the core (Fig. 5A). This gives a pre-industrial to modern $\mathrm{Hg}$ flux increase to sediment of about 6-fold for the Kalya Platform area of the lake. In comparison, maximum $\mathrm{Hg}$ accumulation rates observed in sediment cores from Lake Victoria were $80-130 \mu \mathrm{g} /$ $\mathrm{m}^{2} / \mathrm{a}$ occurring around $1960-1980$, and the ratios of recent to pre-industrial $\mathrm{Hg}$ accumulation were 2.43-2.46 (Campbell et al., 2003). The pre-industrial Hg accumulation in MC1 was low compared to pre-industrial $\mathrm{Hg}$ accumulation observed in cores from remote lakes of Uganda (Yang et al., 2010), which had (preindustrial) sediment deposition rates of about $0.005-0.05 \mathrm{~g} / \mathrm{cm}^{2}$ / a, sediment $\mathrm{Hg}$ concentrations of $50-150 \mathrm{ng} / \mathrm{g}$, and $\mathrm{Hg}$ accumulation rates of $5-30 \mu \mathrm{g} / \mathrm{m}^{2} / \mathrm{a}$. In addition, the MC1 pre-industrial $\mathrm{Hg}$ accumulation rates are low compared to estimates of atmospheric deposition rates for the region based on global atmospheric modelling (Selin et al., 2008), which are about $9 \mu \mathrm{g} / \mathrm{m}^{2} / \mathrm{a}$.

For LT-98-58, the sediment mass accumulation rates in the core range from $0.1-0.2 \mathrm{~g} / \mathrm{cm}^{2} / \mathrm{a}$, with $\mathrm{Hg}$ accumulation rates of about $30 \mu \mathrm{g} / \mathrm{m}^{2} / \mathrm{a}$ below $10 \mathrm{~cm}$, increasing to an average of about $70 \mu \mathrm{g} / \mathrm{m}^{2} / \mathrm{a}$ in the upper $4 \mathrm{~cm}$ of the core (Figs. 2 and 5B). This gives a pre-industrial to modern $\mathrm{Hg}$ flux increase to the sediment of 2-3fold for the Nyasanga/Kahama delta region of the lake, which is more in line with the 2.4 modern to pre-industrial ratio observed 

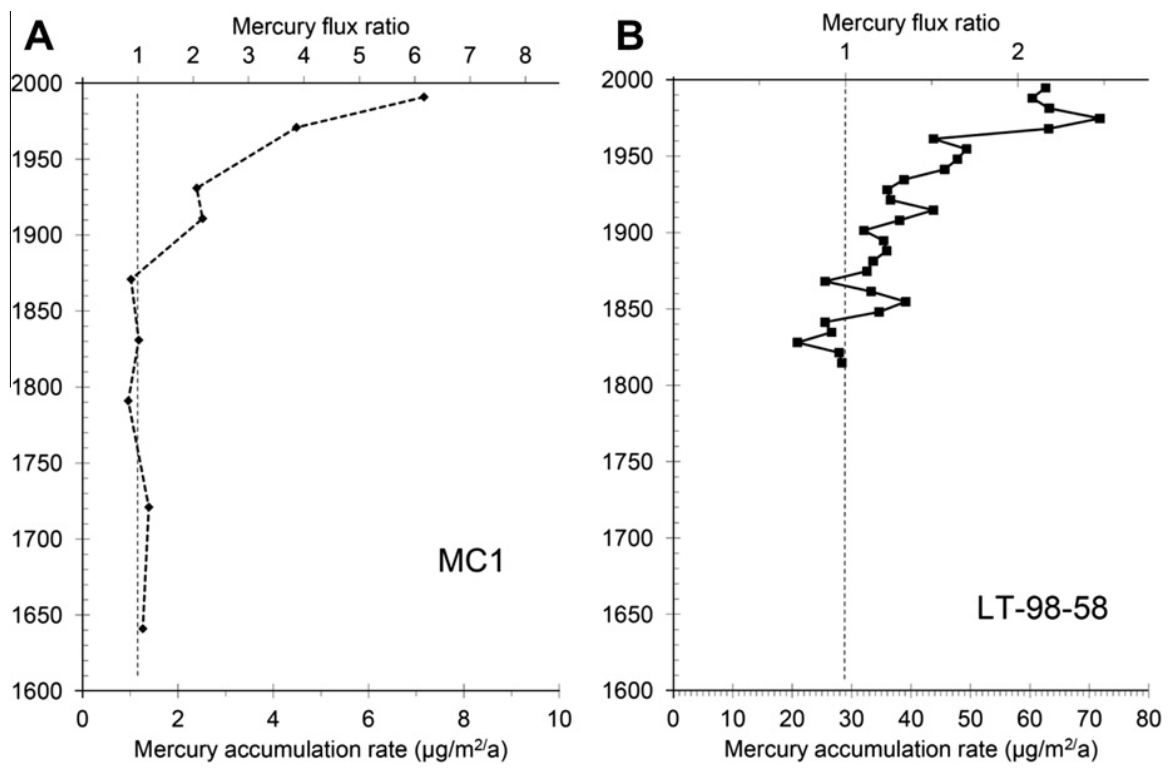

Fig. 5. Mercury accumulation rates $\left(\mu \mathrm{g} / \mathrm{m}^{2} / \mathrm{a}\right)$ in cores and flux ratio to background (pre-1850) accumulation rates for (A) MC1 and (B) LT-98-58.

in Lake Victoria (Campbell et al., 2003) than the 6-fold ratio observed at the MC1 location. Based on the measured and modelled pre-industrial atmospheric $\mathrm{Hg}$ deposition rates for the region, which range within $5-30 \mu \mathrm{g} / \mathrm{m}^{2} / \mathrm{a}$ (Selin et al., 2008; Yang et al., 2010), and considering that the $\mathrm{Hg}$ flux here is substantially higher than at the Kalya Platform area, watershed contribution is likely a substantial part of Hg flux to the Nyasanga/Kahama delta region. The lower ratio of modern to pre-industrial $\mathrm{Hg}$ flux in LT-98-58, therefore, can be explained as a relatively small atmospheric $\mathrm{Hg}$ deposition combined with a relatively large watershed $\mathrm{Hg}$ contribution. There may be an additional contribution of $\mathrm{Hg}$ from contaminated fine-grained sediment transported from other nearby regions of the lake's catchment, including potential $\mathrm{Hg}$ input points such as the Malagarasi River or the Burundi coast.

The pre-1930s Hg concentrations observed in MC1 and LT-9858 are fairly low, about $20 \mathrm{ng} / \mathrm{g}$ (Fig. 4), similar to some historical background $\mathrm{Hg}$ concentrations in other locations in Africa (Kading et al., 2009), but lower than observed in Lake Victoria (Campbell et al., 2003) or in remote lakes of Uganda (Yang et al., 2010), where pre-1930s concentrations were greater than $50 \mathrm{ng} / \mathrm{g}$. Modern $\mathrm{Hg}$ concentrations in MC1 and LT-98-58 are similarly low (predominantly $<50 \mathrm{ng} / \mathrm{g}$ ) when compared to modern $\mathrm{Hg}$ concentrations at regional background sites (80-90 ng/g) at Munekesi and Nyamasenga (Taylor et al., 2005) and Lake Victoria (Campbell et al., 2003), as well as other remote lake sites in Africa (Yang et al., 2010) and elsewhere, such as Nova Scotia and New Zealand (Lamborg et al., 2002). In addition to differences in $\mathrm{Hg}$ accumulation rate and sediment accumulation rate at these sites, these differences in pre1930 and modern $\mathrm{Hg}$ concentrations in this study reflect differences in catchment areas and sediment lithology.

The relative contribution of atmospheric or watershed $\mathrm{Hg}$ from biomass burning to the Lake Tanganyika is difficult to evaluate. Relatively few studies have specifically investigated the impact of $\mathrm{Hg}$ released from wildfires or biomass burning on historic sediment $\mathrm{Hg}$ accumulation. Whereas $\mathrm{Hg}$ concentrations after a fire may be relatively depleted in soils and resulting ash (Amirbahman et al., 2004; Biswas et al., 2007; Burke et al., 2010), atmospheric Hg concentrations increase, predominantly as elemental $\mathrm{Hg}$ vapour, although some fraction of the $\mathrm{Hg}$ is bound to particulate matter (Friedli et al., 2003a,b; Wang et al., 2010). Relative to particulatebound $\mathrm{Hg}$, elemental $\mathrm{Hg}$ vapour is more widely dispersed in the atmosphere because of a longer apparent atmospheric residence time and/or low net atmospheric deposition (Schroeder and Munthe, 1998; Gustin et al., 2008). The results of a study of two lakes in southern California, USA, suggested that high levels of $\mathrm{Hg}$ can remain in the atmosphere following wildfires and be deposited locally as particulate $\mathrm{Hg}$, thus influencing $\mathrm{Hg}$ accumulation on a local level (Rothenberg et al., 2010). In addition, it has been suggested that biomass burning is a potential prevailing source of atmospheric Hg in Africa (Campbell et al., 2003).

There has been substantial land clearing and biomass burning in areas both north and south of the Nyasanga/Kahama delta region. Active fire suppression has been practiced within the Nyasanga/ Kahama watershed for about 50 a because both rivers lie within Gombe Stream National Park (Cohen et al., 2005b; Palacios-Fest et al., 2005). However, this park covers a very small area (14 km N-S along the lakeshore by $\sim 2.5 \mathrm{~km}$ inland), and intentional burning of pasturage and croplands is a regular practice immediately outside of these park boundaries, within a few $\mathrm{km}$ of the core site. The charcoal record recovered from the LT-98-58 (which is overwhelmingly dominated by easily-transported charred grass particles) must, therefore, be viewed as primarily a reflection of regional activities (extensive and persistent burning) as opposed to the specific local history of the park (Cohen et al., 2005b; Palacios-Fest et al., 2005). Charcoal abundance is extremely high throughout the LT-98-58 core (Fig. 6), with very high values in both the late 18th/early 19th century and the late 20th century, and lower values in the mid-19th to mid 20th century, which is thought to generally track human population and agricultural intensity in the region (Palacios-Fest et al., 2005). In contrast, $\mathrm{Hg}$ concentrations and accumulation rates measured in LT-98-58 increase from the 18 th/early 19 th century into the late 20th century, with no evidence of a broad mid 20th century decrease (Figs. 4 and 5). This lack of correlation between charcoal abundance and $\mathrm{Hg}$ accumulation trends is also seen in MC1. In MC1, the charcoal abundance and flux decreases from the late 18th century through the end of the 20th century (Fig. 6), whereas $\mathrm{Hg}$ concentrations and $\mathrm{Hg}$ accumulation rate increases (Figs. 4 and 5). Thus, local biomass burning, inasmuch as it is represented by charcoal abundance, appears to have little relationship to $\mathrm{Hg}$ concentration or $\mathrm{Hg}$ accumulation rates. However, $\mathrm{Hg}$ released to the atmosphere from forest fires can easily travel tens to hundreds of kilometres before wash- 


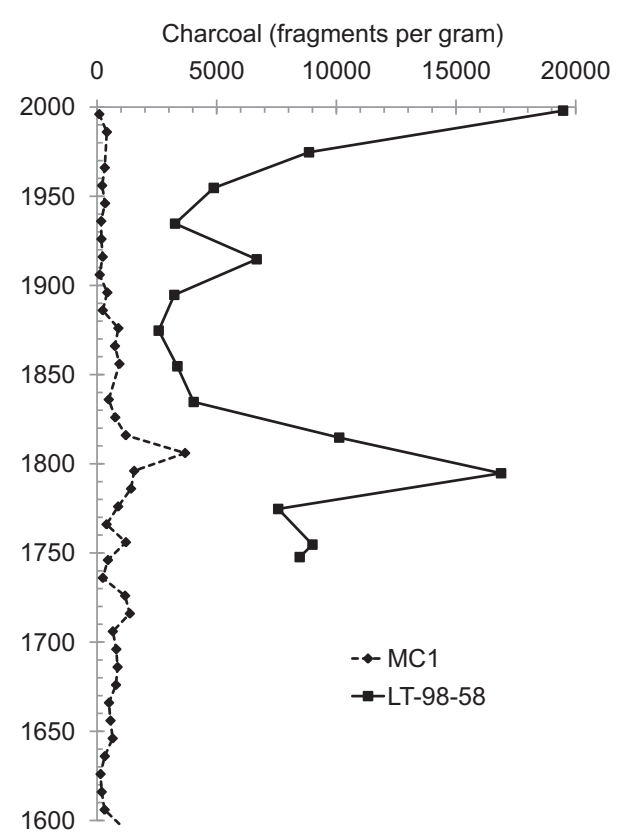

Fig. 6. Charcoal abundance profiles for MC1 and LT-98-58. Data from Palacios-Fest et al. (2005) and Tierney et al. (2010).

ing out as wet/dry deposition (Brunke et al., 2001; Wang et al., 2010). Although initial estimates of $\mathrm{Hg}$ emissions to the atmosphere from global biomass burning show the dominance of the equatorial Asia, boreal Asia, and South America, emissions from Africa are still substantial (Friedli et al., 2009). Consequently, the importance of $\mathrm{Hg}$ deposition from burning on a regional scale and over longer timescales is less clear.

Catchment contribution and sediment focusing are difficult to estimate. The measured unsupported ${ }^{210} \mathrm{~Pb}$ flux in MC1 was approximately $100 \mathrm{~Bq} / \mathrm{m}^{2} / \mathrm{a}$, and $640 \mathrm{~Bq} / \mathrm{m}^{2} / \mathrm{a}$ in LT-98-58. The atmospheric contribution to this unsupported ${ }^{210} \mathrm{~Pb}$ flux, however, has not been measured or modelled. Although there is a model for longitudinal variation for ${ }^{210} \mathrm{~Pb}$ flux for $15-55^{\circ} \mathrm{S}$ in the Southern Hemisphere (Turekian et al., 1977), this geographic range does not match the location of the lake $\left(4-9^{\circ} \mathrm{S}\right)$, and without measured or modelled ${ }^{210} \mathrm{~Pb}$ atmospheric deposition rates a sediment focusing factor cannot be generated. The relatively low $100 \mathrm{~Bq} / \mathrm{m}^{2} / \mathrm{a}$ unsupported ${ }^{210} \mathrm{~Pb}$ flux in MC1 compared to reported values from cores from remote lake sites in Uganda of 377 and $999 \mathrm{~Bq} / \mathrm{m}^{2} / \mathrm{a}$ (Yang et al., 2010) suggests some difference in sediment accumulation or difference in ${ }^{210} \mathrm{~Pb}$ accumulation between these systems.

The contribution of anthropogenic atmospheric $\mathrm{Hg}$ deposition to the coring sites was estimated using the focus-corrected mass accumulation rate approach (Perry et al., 2005; Van Metre and Fuller, 2009). This approach uses a background (i.e., pre-industrial, pre1850) $\mathrm{Hg}$ concentration or background $\mathrm{Hg}$ flux rate to yield an anthropogenic Hg flux value that is then corrected by a focusing factor. The focusing factor, which accounts for the transfer of sediment and associated $\mathrm{Hg}$ from other parts of the lake and watershed to the coring site, can be determined using measurements of ${ }^{210} \mathrm{~Pb}$ deposition. Two variants of this approach were performed for comparison: using background sediment $\mathrm{Hg}$ concentration correction (Eq. (1)) and using background $\mathrm{Hg}$ flux correction (Eq. (2));

Hg flux anthropogenic $=\frac{\left([\mathrm{Hg}]-[\mathrm{Hg}]_{\text {background }}\right) \times \text { MAR }}{\text { focusing factor }}$

$\mathrm{Hg}$ flux $_{\text {anthropogenic }}=\frac{\mathrm{Hg} \text { flux }-\left(\mathrm{MAR}_{\text {background }} \times[\mathrm{Hg}]_{\text {background }}\right)}{\text { focusing factor }}$ where $\mathrm{Hg}$ flux $=\mathrm{Hg}$ accumulation rate, $\mathrm{Hg}$ flux anthropogenic $=$ anthropogenic atmospheric $\mathrm{Hg}$ accumulation rate, $[\mathrm{Hg}]=$ sediment $\mathrm{Hg}$ concentration, $[\mathrm{Hg}]_{\text {background }}=$ background sediment $\mathrm{Hg}$ concentration, MAR = mass accumulation rate, and MAR $_{\text {background }}=$ background mass accumulation rate. Background sediment $\mathrm{Hg}$ concentration and background mass accumulation rate are calculated based on the pre-1850 age model data shown in Figs. 2 and 4. Because there are no measured or modelled ${ }^{210} \mathrm{~Pb}$ atmospheric deposition rates for the region, the ratio of ${ }^{210} \mathrm{~Pb}$ flux measurements for the cores were used for a relative focusing factor of 6.5 and 1 for LT-98-58 and $\mathrm{MC1}$, respectively. Other values used for the two approaches are shown in Table 1.

Using the focus-corrected mass accumulation rate approach, the cores have similar anthropogenic atmospheric $\mathrm{Hg}$ deposition profiles (Fig. 7). Furthermore, the two variations of the approach, background concentration corrected and background flux corrected, produce a similar result. It is noted, however, that the calculated absolute $\mathrm{Hg}$ deposition rate assumes that all atmospheric $\mathrm{Hg}$ falling to the lake surface is deposited in the sediment, and that there are a limited number of cores in this study and no available direct measurements of atmospheric deposition of $\mathrm{Hg}\left(\right.$ or $\left.{ }^{210} \mathrm{~Pb}\right)$. As a consequence, if the ${ }^{210} \mathrm{~Pb}$ accumulation in the cores is low compared to atmospheric ${ }^{210} \mathrm{~Pb}$ deposition, then the estimated $\mathrm{Hg}$ fluxes will change accordingly. Although loss of $\mathrm{Hg}$ from the lake through re-emission to the atmosphere is possible (Amyot et al., 1994), and has been observed in stratified tropical lakes elsewhere (Peretyazhko et al., 2006), a discussion of $\mathrm{Hg}$ geochemistry in Lake Tanganyika is beyond the scope of this study. Also, in some cases, such as in the Peruvian Andes, the majority of $\mathrm{Hg}$ delivered to lake sediments from the watersheds may originate from atmospheric deposition, but on a different time scale than direct atmospheric deposition to the lake (Cooke et al., 2009). Nevertheless, these results support the current assertion that the relatively low ratio (2-3-fold) of modern to pre-industrial Hg flux in the Nyasanga/ Kahama delta region of the lake is explained as a relatively small (anthropogenic) atmospheric component that increases relative to the larger watershed $\mathrm{Hg}$ contribution. The results also suggest that after correcting for changes in watershed contribution with background $\mathrm{Hg}$ concentration (20-23 ng/g), observed increases in $\mathrm{Hg}$ flux to both sites in the lake can be attributed to increases in anthropogenic atmospheric $\mathrm{Hg}$ sources. Furthermore, this suggests and that observed $\mathrm{Hg}$ flux changes at $\mathrm{MC1}$ are largely a result of an increase of anthropogenic atmospheric $\mathrm{Hg}$, which is consistent with the offshore site location, far removed from fluvial influences.

Lastly, consideration is given to what the results of the study imply for the risk and management of $\mathrm{Hg}$ in biota in Lake Tanganyika. Methylmercury, which is produced in freshwater systems as a result of the activity of $\mathrm{SO}_{4}^{-}$and Fe-reducing bacteria (Benoit et al., 2003; Kerin et al., 2006), is biomagnified in the food web in Lake Tanganyika. In a study of fish purchased from fish landings and fishing villages in the north-eastern region of the lake (Campbell et al., 2008), most fish species tested were low in $\mathrm{Hg}(>0.2 \mu \mathrm{g} / \mathrm{g}$ wet weight). These relatively low $\mathrm{Hg}$ concentrations are consistent

Table 1

Values used for focus-corrected mass accumulation rate approach to calculate anthropogenic atmospheric $\mathrm{Hg}$ accumulation in cores. Background (i.e., pre-industrial) $\mathrm{Hg}$ accumulation rate is calculated from pre-1850 age model sediment $\mathrm{Hg}$ concentrations and mass accumulation rates shown in Figs. 2 and 4.

\begin{tabular}{llll}
\hline & LT-98-58 & MC1 & Units \\
\hline Background sediment Hg concentration & 20 & 23 & $\mathrm{ng} / \mathrm{g}$ \\
$\begin{array}{l}\text { Background mass accumulation rate } \\
\quad \text { (sediment flux) }\end{array}$ & 0.15 & 0.0053 & $\mathrm{~g} / \mathrm{cm}^{2} / \mathrm{a}$ \\
$\begin{array}{l}\text { Background Hg accumulation rate (Hg flux) } \\
\text { Focusing factor }\end{array}$ & 29 & 1.2 & $\mu \mathrm{gg} / \mathrm{m}^{2} / \mathrm{a}$ \\
\hline
\end{tabular}


Anthropogenic fallout mercury accumulation rate $\left(\mu \mathrm{g} / \mathrm{m}^{2} / \mathrm{a}\right)$

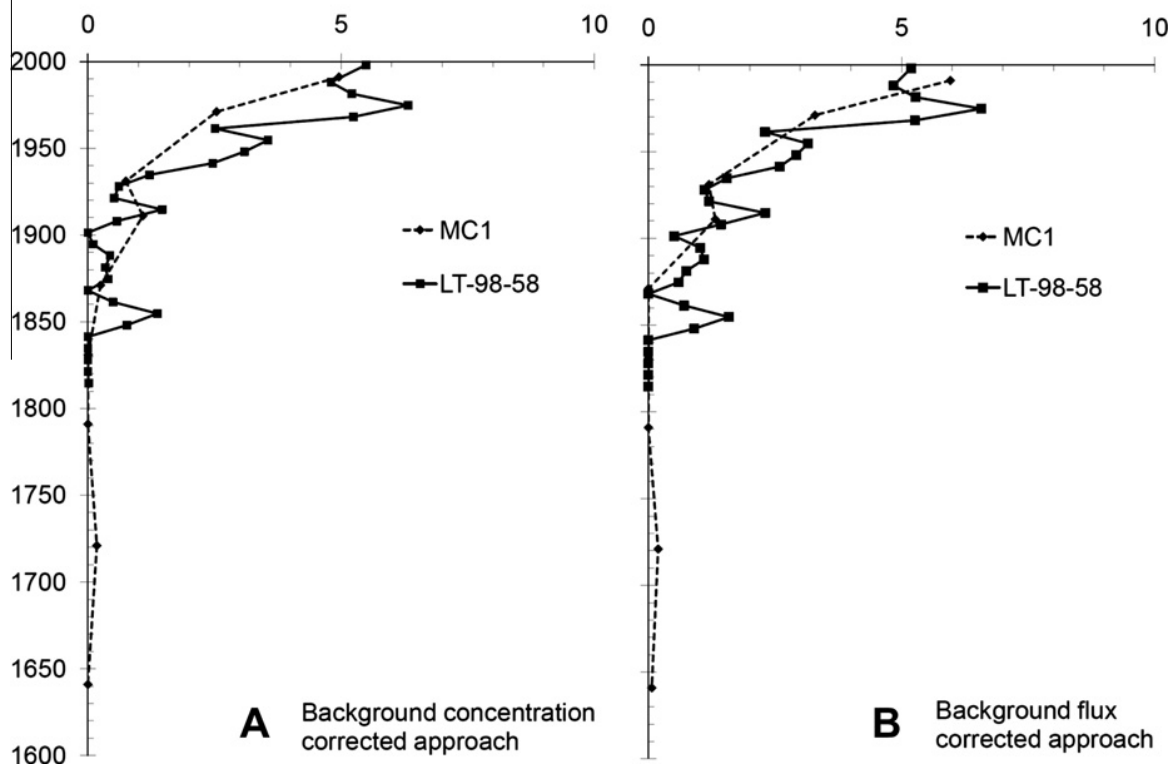

Fig. 7. Anthropogenic atmospheric $\mathrm{Hg}$ accumulation rates $\left(\mu \mathrm{g} / \mathrm{m}^{2} / \mathrm{a}\right)$ in cores MC1 and LT-98-58 calculated by the focus-corrected mass accumulation rate approach using (A) background concentration and (B) background flux corrected variations. Negative $\mathrm{Hg}$ accumulation rates are plotted as having a value of zero.

with the so-called "tropical African mercury anomaly", where concentrations of $\mathrm{Hg}$ in fish from across tropical Africa are lower than those typically reported for fish from freshwater ecosystems elsewhere globally (Black et al., 2011). However two commonly eaten, higher trophic level fish in the Campbell et al. (2008) study were relatively high in $\mathrm{Hg}(>0.5 \mu \mathrm{g} / \mathrm{g}$ wet weight): Lates microlepis $(0.54-0.78 \mu \mathrm{g} / \mathrm{g}$ wet weight) and Polypterus congicus $(1.3 \mu \mathrm{g} / \mathrm{g}$ wet weight). Previous studies of the sources of $\mathrm{Hg}$ to fish in Lake Tanganyika concluded that there are no identifiable point sources, such as $\mathrm{Hg}$ from Au mining (Taylor et al., 2005; Campbell et al., 2008). The results presented in the present study are consistent with that idea, and demonstrate that aside from background-level $\mathrm{Hg}$ contributions from the lake watersheds, the predominant source of $\mathrm{Hg}$ to Lake Tanganyika is anthropogenic and atmospheric from regional and global sources, making watershed management of $\mathrm{Hg}$ a difficult task from a local perspective.

\section{Conclusions}

In summary, differences in $\mathrm{Hg}$ accumulation in the two "lowdisturbance" areas of Lake Tanganyika are attributed to differences in watershed contribution (Kalya Platform area is more distal from a terrigenous sediment source) of background levels of sediment $\mathrm{Hg}$. After correcting $\mathrm{Hg}$ accumulation rates for this background sediment flux, and correcting for relative sediment focusing between sites, the anthropogenic atmospheric $\mathrm{Hg}$ components are the same at the two sites. Thus, $\mathrm{Hg}$ accumulation profiles in the sediment cores can be explained by considering variable sediment accumulation rates and an increasing atmospheric $\mathrm{Hg}$ flux related to both regional and global anthropogenic sources of $\mathrm{Hg}$, which have increased overall from the 19th Century to the present.

\section{Acknowledgements}

Mercury analyses were conducted at Russ Flegal's laboratory at the University of California Santa Cruz. PWS graciously acknowledges continued support from the USGS Coastal and Marine Geology Program. Geochronologies and mass sedimentation rates on core LT-98-58 were determined by Brent A. McKee and others.
We thank James Russell, Chris Johnson and Jessica Tierney for providing data and assistance on lake sediment core MC1. We thank Kiram Lezzar, James McGill and the students of the Nyanza Project for assistance with core collection. The Tanzania Fisheries Research Institute and the Tanzanian Council of Science and Technology authorized and facilitated core collection. The Lake Tanganyika Biodiversity Project (UNDP-GEF) and the Nyanza Project (NSFATM 0223920 and BIO 0383765) provided funding for field research. Manuscript comments were provided by USGS reviewers Geoffrey Ellis, Peter Van Metre and John E. Gray.

\section{References}

Amirbahman, A., Ruck, P.L., Fernandez, I.J., Haines, T.A., Kahl, J.S., 2004. The effect of fire on mercury cycling in the soils of forested watersheds: Acadia National Park, Maine, USA. Water Air Soil Pollut. 152, 313-331.

Amyot, M., Mierle, G., Lean, D.R.S., McQueen, D.J., 1994. Sunlight-induced formation of dissolved gaseous mercury in lake waters. Environ. Sci. Technol. 28, 23662371.

Benoit, J., Gilmour, C.C., Heyes, A., Mason, R.P., Miller, C.L., 2003. Geochemical and biological controls over methylmercury production and degradation in aquatic ecosystems. In: Cai, Y., Braids, O.C. (Eds.), Biogeochemistry of Environmentally Important Trace Elements. American Chemical Society, Washington DC, pp. 262-297.

Biester, H., Bindler, R., Martinez-Cortizas, A., Engstrom, D.R., 2007. Modeling the past atmospheric deposition of mercury using natural archives. Environ. Sci. Technol. 41, 4851-4860.

Biswas, A., Blum, J.D., Klaue, B., Keeler, G.J., 2007. Release of mercury from Rocky Mountain forest fires. Global Biogeochem. Cycles 21.

Black, F.J., Bokhutlo, T., Somoxa, A., Maethamako, M., Modisaemang, O., Kemosedile, T., Cobb-Adams, C., Mosepele, K., Chimbari, M., 2011. The tropical African mercury anomaly: lower than expected mercury concentrations in fish and human hair. Sci. Total Environ. 409, 1967-1975.

Bloom, N.S., Crecelius, E.A., 1987. Distribution of silver, mercury, lead, copper and cadmium in central Puget Sound sediments. Mar. Chem. 21, 377-390.

Brunke, E.G., Labuschagne, C., Slemr, F., 2001. Gaseous mercury emissions from fire in the Cape Peninsula, South Africa, during January 2000. Geophys. Res. Lett. 28, 1483-1486.

Burke, M.P., Hogue, T.S., Ferreira, M., Mendez, C.B., Navarro, B., Lopez, S., Jay, J.A., 2010. The effect of wildfire on soil mercury concentrations in Southern California watersheds. Water Air Soil Pollut. 212, 369-385.

Campbell, L., Verburg, P., Dixon, D.G., Hecky, R.E., 2008. Mercury biomagnification in the food web of Lake Tanganyika (Tanzania, East Africa). Sci. Total Environ. 402, 184-191.

Campbell, L.M., Hecky, R.E., Muggide, R., Dixon, D.G., Ramlal, P.S., 2003. Variation and distribution of total mercury in water, sediment and soil from northern Lake Victoria, East Africa. Biogeochemistry 65, 195-211. 
Cohen, A.S., Kaufman, L., Ogutu-Ohwayo, R., 1996. Anthropogenic threats, impacts and conservation strategies in the African Great Lakes-a review. In: Johnson, T., Odada, E. (Eds.), The Limnology, Climatology and Paleoclimatology of the East African Lakes. Gordon and Breach Publishers, Newark, N.J., pp. 575-624.

Cohen, A.S., Palacios-Fest, M.R., McGill, J., Swarzenski, P.W., Verschuren, D., Sinyinza, R., Songori, T., Kakagozo, B., Syampila, M., O'Reilly, C.M., Alin, S.R., 2005a. Paleolimnological investigations of anthropogenic environmental change in Lake Tanganyika: I. An introduction to the project. J. Paleolimnol. 34, 1-18.

Cohen, A.S., Palacios-Fest, M.R., Msaky, E.S., Alin, S.R., McKee, B., O’Reilly, C.M., Dettman, D.L., Nkotagu, H., Lezzar, K.E., 2005b. Paleolimnological investigations of anthropogenic environmental change in Lake Tanganyika: IX. Summary of paleorecords of environmental change and catchment deforestation at Lake Tanganyika and impacts on the Lake Tanganyika ecosystem. J. Paleolimnol. 34, 125-145.

Cooke, C.A., Balcom, P.H., Biester, H., Wolfe, A.P., 2009. Over three millennia of mercury pollution in the Peruvian Andes. Proc. Nat. Acad. Sci. USA 106, 88308834.

Coulter, G.W., 1991. Lake Tanganyika and its Life. Oxford University Press, Oxford.

Crutzen, P.J., Andreae, M.O., 1990. Biomass burning in the Tropics: impact on atmospheric chemistry and biogeochemical cycles. Science 250, 1669-1678.

Fitzgerald, W.F., Engstrom, D.R., Mason, R.P., Nater, E.A., 1998. The case for atmospheric mercury contamination in remote areas. Environ. Sci. Technol. 32, $1-7$

Foster, R.P., Piper, D.P., 1993. Archean lode gold deposits in Africa: crustal setting, metallogenesis and cratonization. Ore Geol. Rev. 8, 303-347.

Friedli, H.R., Arellano, A.F., Cinnirella, S., Pirrone, N., 2009. Initial estimates of mercury emissions to the atmosphere from global biomass burning. Environ. Sci. Technol. 43, 3507-3513.

Friedli, H.R., Radke, L.F., Lu, J.Y., Banic, C.M., Leaitch, W.R., MacPherson, J.I., 2003. Mercury emissions from burning of biomass from temperate North American forests: laboratory and airborne measurements. Atmos. Environ. 37, 253-267.

Friedli, H.R., Radke, L.F., Prescott, R., Hobbs, P.V., Sinha, P., 2003b. Mercury emissions from the August 2001 wildfires in Washington State and an agricultural waste fire in Oregon and atmospheric mercury budget estimates. Global Biogeochem. Cycles 17.

Gill, G.A., Fitzgerald, W.F., 1987. Picomolar mercury measurements in seawater and other materials using stannous chloride reduction and two-stage gold amalgamation with gas phase detection. Mar. Chem. 20, 227-243.

Gustin, M.S., Lindberg, S.E., Weisberg, P.J., 2008. An update on the natural sources and sinks of atmospheric mercury. Appl. Geochem. 23, 482-493.

Harada, M., Nakachi, S., Tasaka, K., Sakashita, S., Muta, K., Yanagida, K., Doi, R., Kizaki, T., Ohno, H., 2001. Wide use of skin-lightening soap may cause mercury poisoning in Kenya. Sci. Total Environ. 269, 183-187.

Hartnady, C.J.H., 2009. South Africa's gold production and reserves. S. Afr. J. Sci. 105, 328-329.

Ikingura, J.R., Mutakyahwa, M.K.D., Kahatano, J.M.J., 1997. Mercury and mining in Africa with special reference to Tanzania. Water Air Soil Pollut. 97, 223-232.

Kading, T.J., Mason, R.P., Leaner, J.J., 2009. Mercury contamination history of an estuarine floodplain reconstructed from a $\mathrm{Pb}-210$-dated sediment core (Berg River, South Africa). Mar. Pollut. Bull. 59, 116-122.

Kerin, E.J., Gilmour, C.C., Roden, E., Suzuki, M.T., Coates, J.D., Mason, R.P., 2006. Mercury methylation by dissimilatory iron-reducing bacteria. Appl. Environ. Microbiol. 72, 7919-7921.

Kuehn, S., Ogola, J., Sango, P., 1990. Regional setting and nature of gold mineralization in Tanzania and southwest Kenya. Precambrian Res. 46, 71-82.

Lamborg, C.H., Fitzgerald, W.F., Damman, A.W.H., Benoit, J.M., Balcom, P.H., Engstrom, D.R., 2002. Modern and historic atmospheric mercury fluxes in both hemispheres: global and regional mercury cycling implications. Global Biogeochem. Cycles 16.

Landers, D.H., Gubala, C., Verta, M., Lucotte, M., Johansson, K., Vlasova, T., Lockhart, W.L., 1998. Using lake sediment mercury flux ratios to evaluate the regional and continental dimensions of mercury deposition in arctic and boreal ecosystems. Atmos. Environ. 32, 919-928.

McKee, B.A., Cohen, A.S., Dettman, D.L., Palacios-Fest, M.R., Alin, S.R., Ntungumburanye, G., 2005. Paleolimnological investigations of anthropogenic environmental change in Lake Tanganyika: II. Geochronologies and mass sedimentation rates based on C-14 and Pb-210 data. J. Paleolimnol. 34, 19-29.

Palacios-Fest, MR Cohen, A. S, Lezzar, K Nahimana, L Tanner, B.M, 2005. Paleolimnological investigations of anthropogenic environmental change in Lake Tanganyika: III. Physical stratigraphy and charcoal analysis. J. Paleolimnol. 34, 31-49.

Peretyazhko, T., Charlet, L., Muresan, B., Kazimirov, V., Cossa, D., 2006. Formation of dissolved gaseous mercury in a tropical lake (Petit-Saut reservoir, French Guiana). Sci. Total Environ. 364, 260-271.

Perry, E., Norton, S.A., Kamman, N.C., Lorey, P.M., Driscoll, C.T., 2005. Deconstruction of historic mercury accumulation in lake sediments, northeastern United States. Ecotoxicol. 14, 85-99.

Ramlal, P.S., Bugenyi, F.W.B., Kling, G.W., Nriagu, J.O., Rudd, J.W.M., Campbell, L.M., 2003. Mercury concentrations in water, sediment, and biota from Lake Victoria, East Africa. J. Great Lakes Res. 29, 283-291.

Reynolds, E.J., Hanek, G., Mölsä, H., Lindqvist, O.V., 1999. Lake Tanganyika Framework Fisheries Management Plan: Background, Policy considerations and main elements; Research for the Management of the Fisheries on Lake Tanganyika. UN-FAO (Food and Agriculture Organization).

Rothenberg, S.E., Kirby, M.E., Bird, B.W., DeRose, M.B., Lin, C.C., Feng, X.B., Ambrose, R.F., Jay, J.A., 2010. The impact of over 100 years of wildfires on mercury levels and accumulation rates in two lakes in southern California, USA. Environ. Earth Sci. 60, 993-1005.

Schroeder, W.H., Munthe, J., 1998. Atmospheric mercury - an overview. Atmos. Environ. 32, 809-822.

Selin, N.E., Jacob, D.J., Yantosca, R.M., Strode, S., Jaegle, L., Sunderland, E.M., 2008. Global 3-D land-ocean-atmosphere model for mercury: present-day versus preindustrial cycles and anthropogenic enrichment factors for deposition. Global Biogeochem. Cycles 22.

Strode, S., Jaegle, L., Selin, N.E., 2009. Impact of mercury emissions from historic gold and silver mining: global modeling. Atmos. Environ. 43, 2012-2017.

Taylor, H., Appleton, J.D., Lister, R., Smith, B., Chitamweba, D., Mkumbo, O., Machiwa, J.F., Tesha, A.L., Beinhoff, C., 2005. Environmental assessment of mercury contamination from the Rwamagasa artisanal gold mining centre, Geita District, Tanzania. Sci. Total Environ. 343, 111-133.

Tierney, J.E., Mayes, M.T., Meyer, N., Johnson, C., Swarzenski, P.W., Cohen, A.S., Russell, J.M., 2010. Late-twentieth-century warming in Lake Tanganyika unprecedented since AD 500. Nature Geosci. 3, 422-425.

Turekian, K.K., Nozaki, Y., Benninger, L.K., 1977. Geochemistry of atmospheric radon and radon products. Ann. Rev. Earth Planet. Sci. 5, 227-255.

Van Metre, P.C., Fuller, C.C., 2009. Dual-core mass-balance approach for evaluating mercury and ${ }^{210} \mathrm{~Pb}$ atmospheric fallout and focusing to lakes. Environ. Sci. Technol. 43, 26-32.

Veiga, M.M., Meech, J.A., Onate, N., 1994. Mercury pollution from deforestation. Nature 368, 816-817.

Wang, Y.G., Huang, J.Y., Zananski, T.J., Hopke, P.K., Holsen, T.M., 2010. Impacts of the Canadian forest fires on atmospheric mercury and carbonaceous particles in northern New York. Environ. Sci. Technol. 44, 8435-8440.

Weiss-Penzias, P., Jaffe, D., Swartzendruber, P., Hafner, W., Chand, D., Prestbo, E., 2007. Quantifying Asian and biomass burning sources of mercury using the $\mathrm{Hg} /$ $\mathrm{CO}$ ratio in pollution plumes observed at the Mount Bachelor Observatory. Atmos. Environ. 41, 4366-4379.

West, K. 2001. Lake Tanganyika: Results and Experiences of the UNDP/GEF Conservation Initiative (RAF/92/G32) in Burundi, D.R. Congo, Tanzania, and Zambia.

Yang, H.D., Engstrom, D.R., Rose, N.L., 2010. Recent changes in atmospheric mercury deposition recorded in the sediments of remote equatorial lakes in the Rwenzori Mountains, Uganda. Environ. Sci. Technol. 44, 6570-6575. 